\title{
Implementasi Total Quality Management sebagai Upaya Peningkatan Mutu Pendidikan di MAN Model Yogyakarya
}

\begin{abstract}
Ahmad Darmadji*
Abstrak

This research aims to describe the implementation of "total quality management" in an effort to improve the quality of education in MAN(Senior High School) Model of Yogyakarta the expected impact on the surrounding $M A$. in addition, the research also aimed to know the prerequisite in the; implementation of TQM (Total Quality Management) and the constraints and efforts to solve them research conducted in MAN (Senior High School) Model of Yogyakarta using a phenomenological qualitative approach, data collection is done by studying the documentation, observation of nonparticipation, in-depth interviews and focused discussions.

Research results indicate that the implementation of the principle of TQM (Total Quality Management) in MAN (Senior High School) Model of Yogyakarta is reflected from a gradual process and continually improve the quality of the fulfilment of expectations (client) internally and externally through support, active and dynamic participation of some parties. TQM (Total Quality Management) also benefits the MAN (Senior High School) Model of Yogyakarta as an institution in its role as a leader of change, togetherness and cooperation of all components of MAN (Senior High School) Model of Yogyakarta be a prerequisite to effective implementation
\end{abstract}

Penulis adalah dosen tetap dan Ketua Program Studi Pendidikan Agama Islam FIAI UII Yogyakarta.

NO. 2. VOL. I. 2008

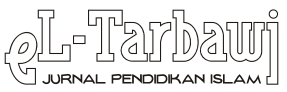


of TQM (Total Quality Management) in improving the quality of education, there are a number of obstacles that can be solved with a commitment to communicate and enhance all the components to work together towards the quality expected.

Hasil penelitian menunjukkan bahwa implementasi prinsip TQM di MAN Model Yogyakarta tercermin dari proses yang bertahap dan terusmenerus dalam peningkatan mutu dengan pemenuhan harapan pelanggan (client) internal maupun eksternal melalui dukungan, partisipasi aktif dan dinamis dari sejumlah pihak. TQM juga memberi manfaat bagi MAN Model sebagai institusi dalam perannya sebagai leader of change. Kebersamaan dan kerjasama seluruh komponen MAN Model Yogyakarta menjadi prasyarat implementasi TQM yang efektif dalam meningkatkan kualitas pendidikan. Sejumlah hambatan yang ada dapat terpecahkan dengan mengkomunikasikannya dan mempertinggi komitmen semua komponen untuk bersama-sama menuju pada kualitas yang diharapkan.

\section{A. Pendahuluan}

Madrasah Aliyah (MA) adalah sekolah berciri khas Islam yang diselenggarakan oleh Departemen Agama (Depag) dalam sistem pendidikan nasional (SK Mendikbud No. 0489/U/1992 dan UU No. 20/2003 tentang Sisdiknas). Kualitas dan layanan MA selama ini dipandang "lebih rendah" dibanding sekolah lain. Akibatnya, masyarakat lebih memilih sekolah selain MA, dan MA dianggap lembaga pendidikan "kelas dua" (Furchan, 2004: 49). Pandangan "miring" di atas antara lain dilihat dari indikator mutu berupa: (1) aktifitas guru dan siswa di madrasah; (2) kreatifitas guru dan siswa; (3) human relation antara guru dan siswa; dan (4) moralitas guru dan siswa (Zaini Hemi, 2004: iv).

Guna peningkatan mutu MA, Depag membentuk cluster madrasah negeri "model" yang memimpin pembangunan madrasah di lingkungannya, juga berperan sebagai agent of change dengan cara "imbas' terhadap madrasah lain guna bersama-sama maju menjadi madrasah yang berkualitas (Fadjar, 1998: 82). Untuk tingkat MA, melalui Development of Madrasah Aliyah Project (DMAP), sejak 1999 dikembangkan Madrasah Aliyah Negeri (MAN) Model. 
Tujuan MAN Model adalah menghasilkan output pendidikan yang memiliki keunggulan aspek: (1) keimanan dan ketaqwaan kepada Tuhan YME, (2) nasionalisme dan patriotisme yang tinggi, (3) wawasan iptek yang luas dan mendalam, (4) motivasi dan komitmen yang tinggi untuk mencapai prestasi dan keunggulan, serta memiliki keperibadian yang kokoh, (5) kepekaan sosial dan kepemimpinan, dan (6) disiplin yang tinggi dan kondisi fisik yang prima. Sasarannya adalah menjadikan MAN Model sebagai lembaga penyelenggara proses pendidikan profesional yang mendemontrasikan proses pembelajaran yang komprehensif, memfasilitasi proses belajar siswa aktif, dinamis, mandiri dan menjadi lembaga pendidikan percontohan yang menyebarluaskan kinerja profesional bagi pembinaan dan pengembangan pengelolaan madrasah lain yang sejenis, negeri maupun swasta, melalui pusat sumber belajar bersama (PSBB) (Pedoman Umum Pengembangan dan Pengelolaan Madrasah Model, 2002: 3). Satu dari 35 MAN Model yang ada adalah MAN Model Yogyakarta yaitu MAN Yogyakarta III (Mayoga).

Kendati upaya peningkatan kualitas lembaga pendidikan selama ini terus dilakukan, namun secara umum perbaikan itu masih dipandang belum berhasil. Setidaknya terdapat dua faktor mengapa upaya perbaikan mutu pendidikan selama ini kurang berhasil (Umedi, 2004: 25-26). Pertama, strategi pembangunan pendidikan selama ini bersifat input oriented atau strategi input-output. Asumsinya bila semua input pendidikan (penyediaan materi ajar, sarana pendidikan, pelatihan guru dan tenaga kependidikan lainnya) telah dipenuhi, maka otomatis lembaga pendidikan (sekolah/ madrasah) menghasilkan output (keluaran) yang bermutu. Ternyata strategi input-output ini tidak sepenuhnya berfungsi pada lembaga pendidikan, tidak seperti pada institusi ekonomi dan industri.

Kedua, belakangan pengelolaan pendidikan lebih bersifat macrooriented yang tergantung pada birokrasi di tingkat pusat. Akibatnya, banyak faktor yang diproyeksikan di tingkat makro (pusat) tidak berjalan sebagaimana mestinya di tingkat mikro (sekolah/madrasah), karena kompleksitas cakupan permasalahan pendidikan tingkat mikro seringkali tidak terpikirkan secara utuh dan akurat oleh birokrasi pusat. Kendati demikian, hal ini belakangan mulai diatasi dengan kebijakan desentralisasi termasuk bidang pendidikan. 
Peningkatan kualitas pendidikan merupakan salah satu prasyarat dalam memasuki era globlalisasi. Keberadaan MA sebagai salah satu lembaga pendidikan Islam tidak lepas dari prasyarat tersebut. Untuk itu peningakat kualitas merupakan agenda utama dalam meningkatkan mutu madrasah agar dapat survive dalam era global. Total quality management (TQM) atau manajemen mutu terpadu (MMT) merupakan konsep peningkatan mutu secara terpadu dalam manajemen yang sudah diterapkan dalam dunia pendidikan kendati masih belum terlalu lama. Laporan penelitian ini berusaha menyoroti implementasi konsep TQM di MAN Model Yogyakarta dengan pertanyaan penelitian: (1) Sejauh mana konsep TQM diterapkan di MAN Model Yogyakarta? (2) Prasyarat apa yang diperlukan agar TQM itu berhasil? (3) Apa kendala yang dihadapi dan bagaimana pemecahannya?

\section{B. Kerangka Teoritik}

Pada konteks total quality management (TQM) atau manajemen mutu terpadu (MMT), mendefinisikan mutu atau kualitas memerlukan pandangan komprehensif, karena terdapat sejumlah elemen agar sesuatu hal dikatakan bermutu atau berkualitas. Elemen dimaksud adalah: (1) kualitas meliputi usaha memenuhi atau melebihi harapan pelanggan; (2) kualitas mencakup produk, jasa, manusia, proses, dan lingkungan; dan (3) kualitas merupakan kondisi yang selalu berubah-dalam arti apa yang dianggap berkualitas saat ini mungkin dianggap kurang berkualitas pada saat yang lain (Fandy Tjiptono \& Anastasia Diana, 2003: 3-4).

TQM atau MMT dapat didefinisikan dari tiga kata yang dimilikinya: total (keseluruhan, terpadu), quality (kualitas, derajat/tingkat keunggulan barang atau jasa), management (tindakan, seni, cara pengendalian, pengarahan). Dariketiganya TQM didefinisikan sebagai"sistemmanajemen yang berorientasi pada kepuasan pelanggan (customer satisfaction) dengan kegiatan yang diupayakan benar sekali (right first time), melalui perbaikan berkesinambungan (continous improvement) dan memotivasi staf/karyawan/orang yang terlibat" (Zulian Yamit, 2001: 181).

Kualitas atau mutu dalam konteks TQM juga merupakan suatu filosophi dan metodologi yang membantu lembaga untuk mengelola perubahan secara totalitas dan sistemik yang meliputi perubahan paradigma, visi, misi 
serta tujuan. Esensinya adalah perubahan kultur, bahwa kualitas adalah ide yang dinamik sebagai konsep yang relatif. Jadi kualitas bukan atribut produk atau jasa saja, melainkan spesifikasi yang digunakan sebagai sarana agar barang atau jasa yang dihasilkan berada di atas standar (Shaleh, 2004: 157).

Kualitas atau mutu memiliki dua aspek yaitu, pengukuran berdasar spesifikasi dan berdasarkan pemenuhan kebutuhan atau tuntutan pelanggan. Artinya suatu produk barang atau jasa disebut berkualitas jika pertama, memenuhi spesifikasi dalam tujuan pembuatan atau pelayanannya (quality in fact) dan kedua, jika memenuhi selera dan kebutuhan pelanggan sehingga meningkatkan keinginan, minat dan kebutuhan mereka (quality in perception) (Shaleh, 2004: 160).

Sejalan dengan hal di atas, pada mulanya TQM juga dipahami sebagai "perpaduan semua fungsi dari perusahaan/institusi ke dalam falsafah holistik yang dibangun berdasarkan konsep kualitas, teamwork, produktivitas, dan pengertian serta kepuasan pelanggan" (Ishikawa, 1993: 135). Selain itu TQM juga dimaknai sebagai "sistem manajemen yang mengangkat kualitas sebagai strategi usaha dan berorientasi pada kepuasan pelanggan dengan melibatkan seluruh anggota organisasi (Santosa, 1992: 33). Dengan demikian TQM menjadi suatu pendekatan dalam menjalankan usaha yang mencoba untuk memaksimumkan daya saing organisasi melalui perbaikan terus menerus atas produk, jasa, manusia, proses, dan lingkungannya.

TQM sebagai pendekatan (approach) hanya dapat dicapai dengan memperhatikan sejumah karakteristik: (1) fokus pada pelanggan (internal \& external); (2) memiliki obsesi tinggi terhadap kualitas; (3) menggunakan pendekatan ilmiah dalam pengambilan keputusan dan pemecahan masalah; (4) memiliki komitmen jangka panjang; (5) membutuhkan kerjasama tim (teamwork); (6) memperbaiki proses secara kontinu; (7) menyelenggarakan pendidikan dan pelatihan; (8) memberikan kebebasan yang terkendali; (9) memiliki kesatuan tujuan; dan (10) adanya keterlibatan dan pemberdayaan karyawan. Sedangkan tujuan sistem kualitas atau mutu adalah memberikan keyakinan bahwa produk atau jasa yang dihasilkan (output/keluaran) memenuhi persyaratan mutu pengguna. Sistem mutu tersebut mencakup jaminan mutu dan pengendalian mutu (Bambang Hadi Wiardjo \& Sulistijarningsih Wibisono, 1996: 4-7) 
TQM tidak bisa lepas dari peran William Edward Deming yang mengangkat teorinya sebagai substitusi scientific management yang dipopulerkan oleh Frederic Winslow Taylor, dan menekankan work harder do their best (Bonsting1, 2001: 7). Dalam scientific management, sebuah pekerjaan dimulai dengan plan, diikuti dengan $d o$, yakni mengerjakan pekerjaan dalam skala kecil, diikuti dengan study untuk mengkonfirmasikan perencanaan dengan hasil uji lapangan, dimodifikasi sesuai hasil studi untuk digunakan dalam skala yang lebih besar. Teorinya disebut fase act (Bonsting1, 2001: 9-10). Secara skematik teori Deming dapat digambaran sebagai berikut:

(4)

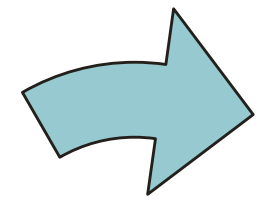

Act

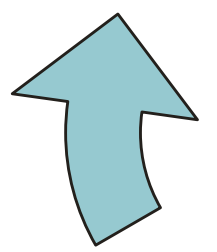

(3)
Study

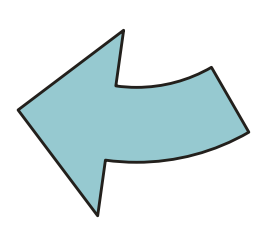

(1)

Plan

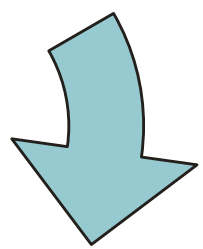

(2)

Do

Gambar 1. Lingkaran Deming (Bonstingl, 2001: 10)

Melalui teorinya ini Deming menekankan perbaikan-perbaikan yang tidak pernah henti, dan setiap apa yang dikerjakan selalu diawali dengan perencanaan, dan perencanaan diilhami dengan hasil yang telah tercapai sebelumnya, sehingga ada perbiakan-perbaikan untuk implementasi rencana berikutnya.

Teori Deming diteruskan Joseph M. Juran. Ia mendefinisikan kualitas adalah "kesesuaian untuk pemakaian", kualitas adalah "terbebas dari 
kesalahan". Juran mengembangkan lingkaran kualitas yang dinamainya dengan "spiral of progress in quality" yang meliputi, customer, product development, operating, marketing, further development, dan lain-lain. Proses kualitas itu dimulai dari dan berakhir pada pelanggan (Bonsting1, 2001: 14). Dengan teori lingkaran spiral tersebut, Juran sebagimana Deming menekankan perbaikan terus-menerus dalam kualitas.

Juran menyampaikan teori Strategic Quality Management (SQM), bahwa setiap bagian dalam organisasi memiliki kontribusi terhadap peningkatan kualitas. Namun yang penting adalah upaya mengadaptasi teori-teori tersebut dalam menajemen pendidikan, dalam konteks pengembangan dan peningkatan kualitas pendidikan yang dilakukan secara holistik, komprehensif namun bertahap dalam prinsip perbaikan tiada henti sebagai inti dari TQM, yakni peningkatan kualitas dalam semua sector dan dilakukan oleh semua orang dalam organisasi serta dilakukan secara terus-menerus. Semua orang dalam TQM adalah manajer untuk bidang kewenangannya (Sallis, 1993: 53). Sejalan dengan pandangan-pandangan Sallis tersebut, Greenwood (1994: 26) menyampaikan bahwa kualitas itu tiada lain adalah "terpengaruhnya atau terpenuhinya permintaan pelanggan, tercapainya tujuan serta dapat menyenangkan para pelanggan tersebut".

Untuk menjamin perbaikan total pada semua orang di semua unit dan dilakukan terus-menerus, Sallis (1993: 48-49) dengan mengadaptasi doktrin Deming menawarkan langkah-langkah penting dalam pengembangan TQM di sekolah, yaitu:

1. Rumuskan tujuan yang konstan untuk perbaikan dalam produk dan layanan, dengan tujuan agar menjadi kompetitif.

2. Gunakan filosofi baru! Sebuah sekolah tidak akan mampu berkompetisi jika terus menerima dan memaafkan keterlambatan, kesalahan, atau melahirkan hasil yang tidak tepat.

3. Berhentilah menggunakan pengawasan publik untuk mencapai kualitas! Pengawasan publik yang dilakukan oleh unit inspeksi tidak menjamin kualitas.

4. Tingkatkan terus kualitas pelayanan dan produk layanan.

5. Lakukan on the job training! Pelatihan merupakan salah satu yang paling penting untuk peningkatan kualitas.

6. Tugas manajemen adalah memimpin bukan mengawasi, pemimpin 
harus mampu berperan untuk mendorong kemajuan dalam proses pelaksanaan pekerjaan agar menghasilkan layanan dan produk terbaik.

7. Hindari rasa takut, yakni bahwa produktivitas pegawai juga dipengaruhi oleh perasaan aman bekerja di tempat dia bekerja.

8. Atasi berbagai kendala hubungan antara unit atas departemen.

9. Posisikan setiap orang dalam institusi untuk bekerja dan melaksanakan transformasi.

Bill Cresch (1996) menyatakan, sistem TQM harus dibangun atas dasar lima pilar sistem yaitu; produk, proses, organisasi, kepemimpinan, dan komitmen. Produk adalah titik pusat untuk tujuan dan pencapaian organisasi. Mutu dalam produk tidak mungkin ada tanpa mutu di dalam proses. Mutu di dalam proses tidak mungkin ada tanpa organisasi yang tepat. Organisasi yang tepat tidak ada artinya tanpa pemimpin yang memadai. Komitmen yang kuat dari bawah ke atas merupakan pilar pendukung bagi semua yang lain. Setiap pilar tergantung pada keempat pilar yang lain, dan kalau salah satu lemah dengan sendirinya yang lain juga menjadi lemah.

TQM merupakan sebuah kelanjutan dalam perjalanan konsep manajemen untuk memperbaiki kualitas produk serta memberi kepuasan bagi pelanggan, baik dalam produk barang, jasa maupun pelayanan lainnya, yakni melalui quality control, quality assurance, dan total quality management (Sallis, 1993: 26). Dalam konteks pendidikan, qualitu control untuk mendeteksi terjadinya penyimpangan kualitas output yang tidak sesuai dengan standar. Standar kualitas ini dapat dipergunakan sebagai tolak ukur untuk mengetahui maju mundurnya sekolah.

System quality assurance, kualitas itu ditentukan sebuah pekerjaan dimulai dan di saat pekerjaan sedang dikerjaan. Dengan demikian, diharapkan dengan proses itu akan menghasilkan output yang memenuhi standar pula. Untuk itu diperlukan mekanisme kontrol (checking) agar semua kegiatan yang dilakukan di sekolah terkondisi dalam standar proses yang ideal tadi. Dengan quality assurance ini pihak sekolah dapat meyakinkan masyarakat bahwa sekolah senantiasa memberikan pelayanan yang terbaik kepaa seluruh muridnya.

Model TQM sebagai penguatan terhadap konsep quality insurance yakni pengembangan kultur agar semua pegawai pada semua lini dan 
tingkatan memiliki sebuah motto yang sama, bagaimana mereka mencapai kualitas yang telah ditetapkan dan mampu membuat pelanggan itu senang dan merasa puas dengan layanan yang mereka berikan, melalui perbaikan terus-menerus (Sallis, 1993: 30).

Saleh (2004: 160) menambahkan adanya bench marking, yaitu berupa kegiatan untuk menetapkan suatu standar, baik proses maupun hasil yang akan dicapai pada periode-periode tertentu. Untuk kepentingan praktis standar tersebut direfleksikan dari realitas yang ada seperti dalam hal perilaku mengajar guru, standar yang ditetapkan adalah dengan merefleksikan salah seorang guru yang dikenal baik dalam mengajarnya (internal bench marking), demikian pula dalam hal standar kualitas pendidikan, direfleksikan dari suatu madrasah yang baik (external banch marking).

\section{Metode Penelitian}

Penelitian dilakukan di MAN Yogyakarta III sebagai MAN Model. Digunakan pendekatan deskriptif kualitatif fenomenologis yang dimaksudkan untuk mendeskripsikan implementasi total quality management (TQM), kondisi prasyarat sehingga TQM bisa diimplementasikan dan hambatan serta pemecahannya. Pengumpulan data dilakukan dengan teknik kajian dokumentasi, wawancara mendalam serta observasi. Analisis data dilakukan sepanjang penelitian (Nasution, 1988: 98) dengan tahapan: analisis saat dan setelah pengumpulan data serta penyajian data secara sistematik yang dilakukan dengan tiga alur: reduksi data, display data dan penarikan kesimpulan atau verifikasi. Trustworthiness atau 'uji' keterpercayaan berupa credibility dan transferability guna menjaga validitas temuan penelitian (Guba \& Lincoln, 1989: 135) dengan: (1) triangulasi sumber dan teknik, dan (2) confirm audit dengan pihak lain yang dianggap competent. 


\section{Hasil Penelitian dan Pembahasan}

\section{Strategi umum pelaksanaan TQM di tingkat MAN Model}

MAN Model Yogyakarta secara kelembagaan, memiliki sejumlah komponen sebagaimana berlaku bagi lembaga pendidikan pada umumnya. Komponen yang dimaksud antara lain subyek didik, input, process, output serta outcome. Semuanya membentuk suatu system yang satu sama lain tidak bisa dipisahkan. Demikian halnya dalam pengelolaan lembaga, ketika mengimplementasikan TQM dalam pengelolaan madrasah, maka tidak lepas dari lima pilar system (produk, proses, organisasi, kepemimpinan dan komitmen) sebagaimana ditegaskan Bill Cresch (1996) di atas. Kelima pilar system tersebut tidak berdiri sendiri namun saling terkait karena masing-masing mempunyai peran.

Implementasi konsep TQM yang berbasis madrasah pada MAN Model dilakukan melalui sejumlah tahapan. Tahapan tersebut tidak lepas dari partisipasi aktif dan dinamis dari masyarakat dan stake holder, orang tua siswa, siswa, guru, tenaga kependidikan dan staf serta institusi yang memiliki kepedulian terhadap madrasah. Berikut gambaran singkat tahapan dimaksud.

Basis indikator mutu atau kualitas kelembagaam MAN Model setidaknya tercermin dari visi dan misi madrasah. Visi MAN Model Yogyakarta: "membentuk siswa menjadi unggul, terampil dan berkepribadian matang (ULTRA PRIMA)" (Dokumen MAN Model Yogyakarta, 2000), sedangkan misinya adalah: (1) Menyelenggarakan pendidikan yang berbudaya keunggulan, kreatifdan inovatif, (2) Membekali siswa dengan life skill baik general life skill maupun specific life skill, (3) Memadukan penyelenggaraan program pendidikan umum dan kejuruan dan (4) Menghidupkan pendidikan ber-ruh Islam, menggiatkan ibadah, memperteguh keimanan dan akhlaqul karimah sehingga memperoleh output yang ULTRA PRIMA (Notulensi Workshop dan Lokakarya, 2000).

Visi 'unggul' dan 'terampil' dijabarkan masing-masing dalam sembilan (9) indicator, sementara visi 'berkeperibadian matang' ditunjukkan dengan 14 indikator (Rumusan Akhir Penjabaran Strategi Pencapai Visi Mayoga, 2002). Secara operasional, dituangkan dalam rencana strategis (Renstra) 
MAN Model Yogyakarta 1999-2008: empat tahun pertama (1999-2003) dan empat tahun kedua (2004-2008). Renstra ditindaklanjuti dengan program jangka panjang dan program tahunan perbidang: bidang kurikulum dan pengajaran, kesiswaan, keuangan dan sarana prasarana, perpustakaan serta pembinaan profesi guru dan karyawan. Program dirancang bersama pusat sumber belajar bersama (PSBB) dan pusat pengembangan madrasah (PPM) yang meliputi program akademik, ekstrakurikuler hingga penggalian dana mandiri (Pedoman Umum Pengelolaan MAN Model, 2002: 10).

Dua aspek penting yang menjadi perhatian dalam upaya pencapaian visi misi di atas adalah kondisi total sumber daya yang tersedia dan prioritas untuk melaksankan program. Saat terdapat keterbatasan sumber daya, maka dimungkinkan mendorong madrasah untuk menentukan skala prioritas dalam melaksanakan program tersebut. Seringkali prioritas ini dikaitkan dengan pertimbangan aspek pertama (sumberdaya dan sumberdana) yang tersedia. Pertimbangan itupun jelas terkait dengan program yang mendukung pencapaian target mutu.

Prioritaspun seringkali tidak dapat dicapai dalam jangka waktu satu tahun ajaran, oleh karenanya dibuat strategi perencanaan dan pengembangan jangka panjang melalui identifikasi kunci kebijakan dan prioritas. Perencanaan jangka panjang ini dapat dinyatakan sebagai strategi pelaksanaan perencanaan yang harus memenuhi tujuan esensial, yaitu: (1) mampu mengidentifikasi perubahan pokok di madrasah sebagai hasil dari kontribusi berbagai program madrasah dalam periode tertentu, dan (2) strategi perencanaan tersebut harus meyakinkan guru, tenaga kependidikan dan staf lain bahwa walaupun perubahan besar diperlukan dan direncanakan sesuai dengan kebutuhan pembelajaran siswa, tetapi mereka disediakan waktu yang cukup untuk melaksanakannya, serta urutan dan logika pengembangan dapat disesuaikan. Aspek penting dari strategi perencanaan ini adalah program dapat dikaji ulang untuk setiap periode tertentu dan perubahan mungkin saja dilakukan untuk penyesuaian.

Evaluasi diri (self assesment) adalah menjadi keniscayaan untuk menganalisa kekuatan dan kelemahan mengenai sumber daya madrasah, personil madrasah, kinerja dalam mengembangkan dan mencapai target kurikulum dan hasil-hasil yang dicapai siswa berkaitan dengan aspek-aspek intelektual dan keterampilan, maupun aspek lainnya. Berdasarkan analisis tersebut madrasah dapat mengidentifikasikan kebutuhan dan merumuskan 
kembali visi, misi, dan tujuan dalam rangka menyajikan pendidikan yang berkualitas bagi siswanya. Monitoring dan evaluasi juga dilakukan untuk menyakinkan apakah program yang telah direncanakan dapat dilaksanakan sesuai dengan tujuan, apakah tujuan telah tercapai, dan sejauh mana pencapaiannya. Karena fokusnya adalah mutu output dan outcome (siswa), maka kegiatan monitoring dan evaluasi harus memenuhi kebutuhan untuk mengetahui proses dan hasil belajar siswa. Secara keseluruhan tujuan monitoring dan evaluasi ini adalah untuk menilai efektivitas dan efisiensi program madrasah dan kebijakan yang terkait dalam rangka peningkatan mutu pendidikan.

Keberhasilan implementasi TQM/MMT di madrasah salah satunya diukur dari tingkat kepuasan pelanggan (client), baik internal maupun external. Dengan kata lain sekolah/madrasah dikatakan berhasiljika mampu memberikan pelayanan sama atau melebihi harapan pelanggan. Mengutif apa yang ditegaskan Greenwood (1994: 27) bahwa pelanggan (client) sekolah atau madrasah dalam implementasi TQM yang dijalankannya adalah (1) siswa menikmati situasi sekolahnya; (2) orang tua siswa puas dengan layanan, peningkatan transparansi dan akuntabilitas sekolah anaknya; (3) institusi tempat pendidikan siswa melanjutkan studi; (4) para pemakai tenaga kerja yang perlu untuk merekrut staf terampil, memiliki keahlian dan berpendidikan sesuai dengan kebutuhan dan (5) negara yang memerlukan pegawai terdidik dengan baik.

Selain tingkat kepuasan pelanggan, keberhasilan pelaksanaan TQM juga dapat dilihat dari indicator lain. Adaptasi TQM di MAN Model selama ini misalnya dapat dilihat dari sejumlah fenomena berikut ini:

(1) Tingkat konsistensi pelayanan umum dan pelaksanaan pembangunan untuk kepentingan peningkatan kualitas SDM (guru, tenaga kependidikan dan staf) terus meningkat.

(2) Kekeliruan dalam bekerja yang berdampak menimbulkan ketidakpuasan dan komplain siswa dan orangua siswa yang dilayani semakin berkurang.

(3) Disiplin waktu dan disiplin kerja semakin meningkat.

(4) Inventarisasi aset madrasah semakin sempurna, terkendali dan tidak berkurang/hilang tanpa diketahui sebab-sebabnya.

(5) Kontrol berlangsung efektif baik dari atasan maupun masyarakat dan stakeholder, sehingga mampu menghemat pembiayaan, mencegah 
penyimpangan dalam pemberian pelayanan umum dan pembangunan sesuai dengan kebutuhan masyarakat.

(6) Pemborosan dana dan waktu dalam bekerja dapat dicegah.

(7) Peningkatan ketrampilan dan keahlian bekerja terus dilaksanakan sehingga metode atau cara bekerja selalu mampu mengadaptasi perubahan dan perkembangan ilmu pengetahuan dan teknologi, sebagai cara bekerja yang paling efektif, efisien dan produktif, sehingga kualitas produk dan pelayanan umum terus meningkat.

Sejatinya implementasi TQM pada MAN Model sebagai lembaga pendidikan tidak hanya memberikan manfaat bagi pelanggan semata, akan tetapi juga memberi manfaat bagi MAN sendiri sebagai institusi dan bahkan bagi orang yang terlibat dalam institusi. Manfaat dimaksud antara lain: (1) terdapat perubahan kualitas produk dan pelayanan, (2) staf lebih termotivasi, terberdayakan, lebih terlatih dan lebih berkemampuan, (3) produktivitas meningkat dengan tetap menekan kebutuhan biaya, dan (4) permasalahan dapat diselesaikan dengan cepat.

Sementara itu, manfaat bagi institusi di masa yang akan datang antara lain adalah: (1) membuat institusi sebagai pemimpin (leader) dan bukan hanya sekedar pengikut (follower), (2) membantu terciptanya tim work, (3) membuat institusi lebih sensitif terhadap kebutuhan pelanggan, (4) membuat institusi siap dan lebih mudah beradaptasi terhadap perubahan, dan (5) hubungan antara staf institusi madrasah lebih mudah.

Berdasarkan hasil wawancara mendalam dengan sejumlah informan dan observasi diketahui bahwa keberhasilan implementasi TQM di MAN Model diperlukan sejumlah prasyarat. Prasyarat dimaksud adalah sebagai berikut:

(1) Komitmen yang tinggi (dukungan penuh) dari semua orang dalam manajemen.

(2) Mengalokasikan waktu secara penuh untuk implementasi TQM

(3) Menyiapkan dana dan mempersiapkan sumber daya manusia yang berkualitas

(4) Melakukan banchmarking pada lembaga lain yang menerapkan TQM, serta

(5) Mempersiapkan mental untuk menghadapi berbagai bentuk 
hambatan

Implementasi TQM pada institusi MAN Model Yogyakarta guna meningkatan mutu pendidikan, tidak akan lepas dari pembicaraan mutu atau kualitas (quality) yang dalam kerangka umum mengandung makna tingkat keunggulan suatu produk (barang maupun jasa), baik yang tangible maupun yang intangible. Dalam konteks pendidikan, mutu atau kualitas mengacu pada proses dan hasil pendidikan. Pada proses pendidikan yang bermutu terlibat berbagai input seperti bahan ajar, metode pembelajaran, sarana madrasah, dukungan administrasi dan sumber daya lainnya serta penciptaan suasana yang kondusif. Manajemen madrasah berfungsi mensinkronisasikan berbagai input tersebut atau mensinergikan semua komponen dalam interaksi (proses) pembelajaran baik antara guru dan siswa di kelas maupun di luar kelas; baik konteks kurikuler maupun ekstrakurikuler, baik dalam lingkup subtansi yang akademis maupun yang nonakademis dalam suasana yang mendukung proses pembelajaran. Mutu dalam konteks "hasil pendidikan" mengacu pada prestasi yang dicapai oleh madrasah pada setiap kurun waktu tertentu (akhir semester, akhir tahun atau akhir proyek DMAP). Prestasi yang dicapai (student achievement) dapat berupa hasil test kemampuan akademis siswa maupun prestasi bidang non-akademis seperti prestasi di cabang olah raga, seni atau keterampilan tertentu. Bahkan prestasi madrasah dapat berupa kondisi yang intangible seperti suasana disiplin, keakraban, saling menghormati, kebersihan dan sebagainya.

Antara proses dan hasil pendidikan yang bermutu saling berhubungan. Akan tetapi agar proses yang baik itu tidak salah arah, maka mutu dalam arti hasil (ouput) harus dirumuskan lebih dahulu oleh madrasah, dan jelas target yang akan dicapai untuk setiap tahun atau kurun waktu lainnya. Berbagai input dan proses harus selalu mengacu pada mutu-hasil (output) yang ingin dicapai. Dengan kata lain tanggung jawab madrasah dalam school based quality improvement bukan hanya pada proses, tetapi tanggung jawab akhirnya adalah pada hasil yang dicapai. 


\section{Kepemimpinan Kepala Madrasah dalam Implementasi TQM di MAN Model}

Kepemimpinan merupakan salah satu pilar sistem TQM sebagaimana disebutkan di atas. Dalam konteks MAN Model, pilar tersebut berada pada kepemimpinan kepala madrasah dibantu sejumlah Kepala Urusandi sekolah lain biasanya disebut Wakil Kepala Sekolah. Kepemimpinan Mayoga selama menjadi MAN Model dipimpin tiga orang kepala (Drs. Tlm, Drs. Skd dan Dra. SST) yang masa/lama waktu kepemimpinan masing-masing tidak sama.

Kepemimpinan yang kuat nampak menjadi tonggak awal menuju pada performa dalam peningkatan kualitas MAN Model dengan segala tanggungjawabnya. Kekuatan kepemimpinan pada ketiga Kepala MAN Model yang ditunjukkan dengan kekhasannya masing-masing. Kekuatan kepemimpinan ketiga Kepala MAN Model antara lain terletak pada kedisiplinan. Bila pemimpin MAN Model pertama mewujudkan kedisiplinan lebih bersifat legal-formalistik yang berpatokan pada juklak juknis, sementara pada kepemimpinan Kepala MAN yang kedua diwujudkan dalam bentuk optimalisasi sistem dan kenyamanan kerja melalui sentuhan humanitas sosial. Sedangkan kepala yang ketiga kekuatan kedisiplinannya yang lebih menonjol terletak pada penanaman performa kinerja yang harus selalu optimal, kendati terkesan mengesampingkan aspek humanitas sosial.

Pada tingkat operasional, kepala madrasah adalah orang yang terdepan mengkoordinasikan upaya meningkatkan pembelajaran yang bermutu. Kepala madrasah/sekolah diangkat untuk menduduki jabatan yang bertangggung jawab mengkoordinasikan upaya bersama mencapai tujuan pendidikan pada level madrasah masing-masing.

Secara umum, di Indonesia potret kualitas kepala madrasah dilihat dari kreativitas dan inovasinya masih memprihatinkan (Nurhayati Djamas, 2005: 4). Kepala madrasah memang bukan satu-satunya yang determinan bagi efektif- tidaknya suatu madrasah, karena masih banyak faktor lain yang turut menentukan. Dalam persepektif kebijakan pendidikan Nasional terdapat tujuh peran utama kepala sekolah: sebagai pendidik, manajer, administrator, supervisor, leader, pencipta iklim kerja dan wirausahawan. Terlepas dari itu semua, bahwa sejauh mana kepala sekolah dapat 
mengoptimalkan segenap peran yang diembannya secara langsung maupun tidak langsung, dapat memberikan kontribusi terhadap peningkatan mutu pendidikan di sekolah.

Dalam menerapkan TQM pada MAN Model, seorang kepala madrasah dituntut dan telah berhasil membangun efektivitas maupun efisiensi pendayagunaan sumber-sumber pendidikan yang ada. Disamping itu kepala madrasah juga dituntut mampu merumuskan dan mensosialisasikan misi dan visi madrasah pada seluruh staff, mengembangkan filsafat mutu dalam mencapai tujuan yang ditetapkan, bahkan pada MA lain yang berada di sekitarnya. Dengan demikian konsep "kualitas" pendidikan benar-benar dipahami oleh komponen madrasah yang terlibat langsung atau tidak langsung.

Kepala MAN sebagai pemimpin berperan dalam implementasi program TQM mulai dari menetapkan tujuan hingga alokasi waktu yang cukup. Kepemimpinan organisasi yang umum digunakan dapat dibedakan dalam empat model gaya kepemimpinan yaitu: model autocrasi, model feudal, model egalitarian, model anarchic. Model kepemimpinan yang cocok dengan budaya TQM adalah model egalitarian, karena pada model ini seorang pemimpin memberikan kebebasan kepada bawahan dan rekan kerja. Pengambilan putusan dan pengelolaan tentang berbagai kebijakan penting pada madrasah dilakukan oleh sebuah komite dan tidak dilakukan secara individual oleh seorang kepala MAN Model sendiri karena terdapat Dewan Madrasah yang setara dengan Komite Sekolah. Oleh karenanya, kendati terdapat kepala madrasah yang punya kewenangan, namun tidak berarti semua kewenangan sepenuhnya ada padanya.

Melihat fenomena tersebut kiranya upaya untuk menciptakan kondisi yang kondusif dalam mencapai tujuan pendidikan adalah mutlak membutuhkan budaya manajemen kualitas. Dan TQM adalah salah satu alternatif yang harus diterapkan dalam lembaga madrasah lain terlebih MAN Model punya "kewajiban" untuk menyebarkan imbas positif ini pada MA lain yang berada di sekitarnya. Dengan demikian diharapkan efektivitas MAN Model sebagai agent of change akan dapat terwujud secara sempurna.

Akhirnya tidak berlebihan bila dikatakan bahwa kepemimpinan Kepala madrasah adalah salah satu elemen kunci keberhasilan implementasi TQM. 
Hal ini juga mesti didukung dengan kepemimpinan kepala madrasah yang kuat, efektif mengelola guru, tenaga kependidikan dan staf, memiliki team work yang kompak, cerdas dan dinamis. Dengan demikian partisipasi warga madrasah dan masyarakat akan terus meningkat dan lembaga menjadi memiliki akuntabilitas yang tinggi.

\section{Kendala atau hambatan TQM sebagai wujud peningkatan kualiatas}

Implementasi konsep manajemen apapun selalu dihadapkan pada hambatan tertentu yang menjadi kendala. Demikian juga pada implementasi TQM yang terjadi di Mayoga saat menjadi MAN Model. Sejumlah hambatan yang terjadi, sebagian di antaranya — meminjam bahasa Deming (Soegito, 2002: 14) cukup menjadi "penyakit yang mematikan" dalam peningkatan kualitas. Empat "penyakit" itu di antaranya yaitu:

1) Kurang konstannya tujuan, sehingga MAN sebagai lembaga terhambat untuk mengadopsi kualitas sebagai manajemen;

2) Masih adanya pemikiran jangka pendek dari sejumlah guru, tenaga kependidikan, staf dan bahkan kadang orangtua siswa;

3) Adanya evaluasi individual yang hanya dilakukan melalui skala pertimbangan atau laporan semester atau laporan tahunan; dan

4) Delegasi dan kepemimpinan yang kurang baik dan adanya harapan yang terlalu berlebihan.

Selain itu, permasalahan yang dihadapi di lapangan adalah masih adanya sikap mental sebagian pengelola madrasah yang kurang sejalan dengan semangat peningkatan mutu, kurang adanya tindak lanjut dari evaluasi program, gaya kepemimpinan yang kadang kurang mendukung karena pendeknyanya masa kepemimpinan periode MAN Model—satu periode MAN Model ( 5 tahun) dipimpin tiga orang Kepala, kurangnya rasa memiliki para pelaksana pendidikan dan belum membudayanya prinsip melakukan sesuatu secara benar dari awal.

Kunci untuk mengatasi hambatan di atas adalah mengkomunikasikan dan mensosialisasi perubahan pada sistem manajemen kepada semua pihak yang terlibat. Hal inimencakup membangun komitmen untuk perubahan dan partisipasi semua pihak terkait dan memberdayakan tim kerja. Komitmen untuk merubah pendekatan organisasi dalam hal pelayanan bermula dari 
tingkat top manajer (Kepala dan para Kepala Urusan), tetapi perubahan itu sendiri dimanifestasikan oleh seluruh staf pada semua lapisan.

\section{Kesimpulan}

Penerapan TQM sebagai upaya peningkatan mutu pendidikan tidak bisa berhasil secara instant namun perlu proses yang sistematis. Implementasi prinsip TQM di MAN Model Yogyakarta tercermin dari proses yang bertahap dan terus-menerus dalam peningkatan mutu dengan pemenuhan harapan pelanggan (client) baik pelanggan internal maupun eksternal. Proses dan tahapan itu terwujud atas dukungan serta partisipasi aktif dan dinamis dari masyarakat dan stake holder, orang tua siswa, siswa, guru, tenaga kependidikan dan staf serta pihak lain yang punya perhatian untuk meningkatkan kualitas MAN Model khususnya dan pendidikan pada umumnya. Implementasi TQM juga tidak hanya memenuhi harapan client namun juga memberi manfaat bagi MAN Model sebagai institusi dalam perannya sebagai leader of change. Mewujudkan kondisi ideal sebagai prasyarat di mana implementasi TQM dapat efektif, diperlukan kebersamaan dan kerjasama seluruh komponen penyelenggara pendidikan di MAN Model Yogyakarta dengan misi yang sama yakni meningkatkan kualitas pendidikan. Kendati demikian sejumlah hambatan tetap ditemukan, namun dapat terpecahkan dengan mengkomunikasikannya dan mempertinggi komitmen semua komponen untuk bersama-sama menuju pada kualitas yang diharapkan.

\section{DAFTAR PUSTAKA}

Bambang Hadi Wiardjo dan Sulistijarningsih Wibisono (1996). Memasuki pasar internasional dengan ISO 9000, sistem manajemen mutu. Jakarta: Ghalia Indonesia.

Bonstingl, J.J. (2001). Quality of school. California: Corwin Press

Bush, T. (1986). Theories of educational management. London: Paul Chapman Publishing

Departemen Agama RI (2002a). Pedoman umum pengembangan dan 
pengelolaan Madrasah Model. Jakarta: Dirjen Bagais Depag RI.

Departemen Agama RI. (2002b). Pedoman umum pengelolaan Pusat Sumber Belajar Bersama (PSBB). Jakarta: Dirjen Bagais Depag RI.

------. (2002c). Total quality management. Jakarta: Dirjen Bagais Depag RI

Fadjar, A.M. (1998). Madrasah dan tantangan modernitas. Bandung: Mizan

Fandy Tjiptono \& Anastasia Diana (2003). Total quality management (TQM). Yogyakarta: Penerbit Andi

Furchan, A. (2004). Transformasi pendidikan Islam di Indonesia: Anatomi keberadaan Madrasah dan PTAI. Yogyakarta: Gama Media

Greenwood, M.S. and Helen J.G. (1994). Total quality management for school. Wiltshire: Chassell

Guba, E.G \& Lincoln, Y. S. (1989). Naturalistic inquiry. Beverley Hills: Sage Publication

Nasution, S. (1988). Metode penelitian naturalistik/kualitatif. Bandung: Tarsito

Nurhayati Djamas (2005). Madrasah mandiri. Jakarta: Puslitbang Pendidikan Agama dan Keagamaan.

Sallis, E. (1993). Total quality management in education. Philadelphia: Cogan Page

Shaleh, A.R. (2004). Madrasah dan pendidikan anak bangsa: Visi, misi dan aksi. Jakarta: Raja Grafindo Persada

Soegito, Total Quality Management. Semarang: UNNES, 2002.

Soewarso Hardjosoedarmo (2002). Total quality management. Yogyakarta: Andi.

Umedi (2004). Manajemen mutu berbasis sekolah/madrasah (MMBS/M). Jakarta: Pusat Kajian Mutu Pendidikan.

Undang-undang, Nomor 20, Tahun 2003, tentang Sistem Pendidikan Nasional. 
Zulian Yamit (2001). Manajemen kualitas produk dan jasa. Yogyakarta: CV Adipura

Zaini Hemi (2004). Persepsi masyarakat merhadap mutu pendidikan Madrasah sebagai pendidikan Islam. (Thesis Magister, tidak diterbitkan). Yogyakarta: PPs UIN Sunan Kalijaga Yogyakarta. 